5. The PAH Continuum: Pedagogy, Andragogy and Heutagogy https://heutagogycop.wordpress.com

DOI https://doi.org/10.30525/978-9934-26-110-7-78

\title{
ОСОБЛИВОСТІ ВИКЛАДАННЯ ІНОЗЕМНОЇ МОВИ В МАГІСТРАТУРІ СТУДЕНТАМ БУДІВЕЛЬНИХ СПЕЦІАЛЬНОСТЕЙ У КИЇВСЬКОМУ НАЦІОНАЛЬНОМУ УНІВЕРСИТЕТІ БУДІВНИЦТВА І АРХІТЕКТУРИ
}

\author{
Букіна Ю. О. \\ старший викладач кафедри мовної підготовки і комунікаиії \\ Київський начіональний університет будівництва і архітектури
}

Сметанська М. I.

кандидат філологічних наук, доиент кафедри мовної підготовки і комунікації

Київський національний університет будівництва і архітектури м. Київ, Україна

Одним із найважливіших завдань вищої школи $\epsilon$ забезпечення усвідомленої діяльності студентів у процесі вивчення іноземних мов. В умовах технічного навчального закладу, безперечно, слід неодмінно враховувати особливості лексичного матеріалу зі словників технічних термінів, посібників та підручників 3 базових дисциплін для майбутніх фахівців у галузі будівництва і архітектури. А тому викладачам іноземних мов, які готують магістрів до їхньої майбутньої праці за будівельними спеціальностями, слід створити дієву мотивацію для вивчення предмета.

Як відомо, протягом останніх років у системі вищої освіти України відбулися зміни, пов'язані 3 виходом на новий рівень підготовки спеціалістів за вимогами Болонської конвенції, переходом на дворівневу модель підготовки спеціалістів (бакалаври та магістри), введенням нових освітніх стандартів. А це передбачає здійснення підготовки в спеціальних умовах скорочення аудиторних занять та перегляду деяких аспектів викладання іноземних мов.

Обсяг дисципліни «Наукова іноземна мова» для магістрів становить тільки 30 академічних годин. Відтак слід вдаватися до таких методів i 
технологій, застосування яких призведе до оптимального засвоєння матеріалу під час самостійної роботи.

В «Загальноєвропейських компентенціях володіння іноземною мовою», створених робочою групою Ради Свропи, за допомогою детальних дескрипторів подаються характеристики трьох рівнів володіння: елементарного,самостійного та вільного, кожен з яких відповідно поділяється також ще на два підрозділи. Таким чином,дескриптори описують шість рівнів володіння іноземною мовою, що позначаються латинськими літерами: A1, A2, B1,B2, C1, С2.[3, с. 5]

Перехід на дворівневу систему вищої професійної освіти ставить за мету підготувати спеціалістів, які володіють повним рядом загальнокультурних та професійних компетенцій. [2, с. 24] Серед них найбільш актуальним є досягнення такого рівня володіння іноземною мовою, який забезпечує можливість найбільш ефективної реалізації професійної діяльності як на загальноукраїнському, так і на міжнародному ринку праці.

Сучасні методики спрямовані на розвиток навичок мовного навчання не лише на загальні, але й на суто професійні теми. Тим більше, що тепер у випускників ВНЗ є можливість стажування і роботи за кордоном. Не становлять винятку і студенти-магістранти Київського національного університету будівництва і архітектури.

В даній статті ми прагнемо акцентувати увагу на особливостях викладання іноземних мов для студентів-магістрантів будівельних спеціальностей. Будівельна галузь,безперечно, вносить суттєвий вклад в конкурентоздатність та процвітання національної економіки. Навчання іноземним мовам студентів-магістрантів з будівельних спеціальностей, тобто у немовних ВНЗ, цілковито відповідає вимогам Європейського стандарту $\mathrm{C} 1$ i спрямоване на оволодіння іноземною мовою для професійних (LSP) та академічних (LAP) цілей на досконалому рівні.

В процесі вивчення іноземної мови магістранти працюють над науковим проектом, виконують аннотування та реферування статей, беруть участь в зарубіжних конференціях, вивчають актуальну загальнонаукову та спеціальну літературу.

Хочемо поділитися досвідом роботи кафедри мовної підготовки i комунікації КНУБА зі студентами-магістрантами будівельних спеціальностей. Для більшої чіткості сприйняття наших узагальнень позначатимемо окремі позиції арабськими цифрами.

1. Науковий проєкт - це самостійна організована діяльність студентів- магістрантів, що здійснюється за допомогою активного консультування керівником проекту і спрямована на пошук вирішення теоретично або практично значимої проблеми. 
Зауважимо, що проектна робота не пов'язана з графіком навчального процесу. Вона зреалізовується протягом усього навчального року, включаючи як період занять, так і канікулярний час.

2. Реферати. На даний час паралельно із науковим перекладом широкого втілення набувають нові типи і види технічного перекладу. До них належить реферативний переклад та аннотування.

Реферат $\epsilon$ одним із самостійних засобів наукової інформації. Він також може бути не лише виконаним у письмовій формі, але й виголошеним перед компетентною публікою у формі усної доповіді.

3. Аннотація - коротка характеристика змісту вже опублікованого дослідження або ж рукопису.

За обсягом змісту аннотованого документа та за принципом читацького призначення зазвичай в аннотації цілковито характеризується об’єкт дослідження. [1, с. 12] Проте для студентів будівельних спеціальностей найбільший інтерес становлять такі з них,які мають рекомендальний спеціалізований характер.

4. Наукова конференція. Наукові конференції, круглі столи 3 дискусіями, підготовка видань збірників студентських наукових робіт зміцнюють традиції підтримки студентської наукової діяльності, формують у молодого покоління мотивацію до наукової роботи, виховують у студентів-магістрантів творче ставлення до їхньої майбутньої професії.

5. Вивчення актуальної загальнонаукової літератури $є$ невід'ємною ланкою в програмі магістратури. Адже про зарубіжні досягнення в галузі науки студенти-магістранти передусім дізнаються з публікацій іноземних монографій, наукових збірників, альманахів, журнальних статей.

Ми поділилися досвідом роботи у викладанні іноземних мов для студентів-магістрантів, які опановують будівельні спеціальності. Під час формування робочої програми ми намагались гармонійно поєднати традиційні методи навчання іноземних мов із новаціями, орієнтованими на ефективне використання мовних знань у їхній майбутній професійній діяльності.

Робота 3 магістрантами складна, оскільки викладач дисципліни «Наукова іноземна мова» не мусить обмежуватись у своїй роботі суто філологічними знаннями. Бо тільки тоді, коли він проходить процес своєрідного «занурення» в глибину наукових досліджень магістранта, це стає запорукою результату високого рівня. Таке взаєморозуміння та поєднання інтересів Учителя и Учня, безумовно, в недалекому майбутньому сприятиме i зміцненню будівельної галузі зокрема, і стабільності економічного процвітання країни загалом. 


\title{
Література:
}

1. Вейзе А.А., Коношева А.В. Практическое пособие по обучению реферативному переводу. Минск: МГЛУ, 1997.

2. Камынина Т.П., Моисеева Е.В. Информационная культура как основа профессиональной компентенции будущего специалиста. Проблемы лингвистики, методики обучения иностранным язиком и литературоведению в свете международной коммуникации. Материалы III международно научной практической конференции 24-25 марта 2011 г. Уфа: Изд-во БГПУ, 2011. 324с.

3. Общеевропейские компетенции владения иностранным языком: изучение, преподавание, оценка. Совет Европы. Департамент современных языков, Страсбург. Московский государственный лингвистический университет, 2003 г. - 256 с.

DOI https://doi.org/10.30525/978-9934-26-110-7-79

\section{ОРГАНІЗАЦІЯ ГРУПОВОЇ НАВЧАЛЬНОЇ ДІЯЛЬНОСТІ СТУДЕНТІВ ПІД ЧАС ДИСТАНЦІЙНОГО ВИВЧЕННЯ СУЧАСНОЇ УКРАЇНСЬКОЇ ЛІТЕРАТУРНОЇ МОВИ}

\author{
Климович С. М. \\ кандидатка філологічних наук, \\ доцентка кафедри украӥнської філології та журналістики \\ Херсонський державний університет \\ Мартос C. A. \\ кандидатка філологічних наук, \\ доцентка кафедри украӥнської філології та журналістики \\ Херсонський державний університет \\ м. Херсон, Украӥна
}

Цілісна система навчальної діяльності здобувачів вищої освіти - це поєднання фронтальної, групової та індивідуальної діяльності. Вони вирізняються кількістю студентів та способом організації їх діяльності. Групова навчальна діяльність гармонійно поєднує індивідуальну й соціальну орієнтації в розвитку професійних здібностей здобувачів вищої освіти. Групова форма роботи студентів-філологів виконує такі основні завдання: конкретно-пізнавальне, яке пов'язане безпосередньо 3 